\title{
How Selected Energy Commodity Prices Volatility Impacts Gross Domestic Product (GDP) Fluctuation with Respect to Selected European Countries
}

\author{
Robert RANOSZ ${ }^{1)}$, Barbara KOWAL
}

1) Ph.D., DSc, Eng.; AGH University of Science and Technology, Faculty of Mining and Geoengineering, Cracow, Poland; email: rranosz@agh.edu.pl

2) Ph.D., Eng.; AGH University of Science and Technology, Faculty of Mining and Geoengineering, Cracow, Poland; email: bkowal@agh.edu.pl

http://doi.org/10.29227/IM-2020-01-15

Submission date: 01-12-2019 | Review date: 12-01-2020

\begin{abstract}
The article examines price volatility of the following energy raw materials: uranium, coal, crude oil and natural gas, and its influence on GDP fluctuation with regard to selected European countries. The study was carried out using linear regression approach, in which the volatility of raw materials prices was determined as independent variables and GDP fluctuation as a dependent variable. The article examines 33 European countries and the examined period covered 28 years (from 1990 to 2018). As demonstrated in the study, energy raw materials prices volatility influences GDP fluctuation, especially in the countries involved in their extraction and processing. Attention was also drawn to the fact that uranium and coal are the most significant energy raw materials for the European countries. In the case of crude oil, its volatility turned out to be significant only for two countries, i.e. Norway and the Russian Federation. It was a surprise that natural gas prices volatility slightly affects GDP fluctuation in selected European countries.
\end{abstract}

Keywords: gross domestic product, energy raw materials, price volatility, GDP

\section{Introduction}

The article discusses the study on the influence of energy raw materials prices volatility on GDP fluctuation with regard to selected European countries. As it can be assumed, the prices (their volatility, to be precise) of raw materials such as: uranium, coal, crude oil or natural gas, can positively or negatively influence the economic growth of the European countries. There are many factors influencing the economic development of individual countries of course, like demand for consumer goods, investments or the amount of taxes. Nevertheless the authors focused on the previously mentioned energy resources in the article. The energy raw materials prices may have direct or indirect impact on the aforementioned economic factor. The direct impact relates to the extraction and processing of a particular energy raw material by a selected country, while indirect impact may affect GDP of a selected country through its influence on prices of, e.g. of consumer goods, production or inflation. This thesis is confirmed by the research conducted by A. Geis, who states that influence of crude oil prices on such parameters as production and inflation can be observed both in the long and short term in the European Union countries [1]. Within the framework of the research carried out by Hamilton J.D., the author claims that economic activity and crude oil prices have negative correlation [2]. Nevertheless, it should be pointed out that crude oil prices - being the main focus of the majority of scientific publications - are continuously losing importance with respect to GDP development in selected countries [3]. It results, among other things, from the fact that the majority of developed economies have significantly improved the efficiency of the raw material's consumption [4]. An upturn in the consumption of crude oil is related to implementation of a worldwide trend aimed at reducing $\mathrm{CO}_{2}$ emissions to atmosphere, and the crude oil itself has an essential meaning in this respect. In terms of significance, the coal is second and natural gas is third in the classification [5]. As opposed to crude oil, in the case of coal, reduction of its consumption may result in decline of GDP indicator in particular countries, especially the countries outside the Organisation for Economic Co-operation and Development (OECD) [6]. The prices of the energy raw materials in question directly translate into energy prices, which in turn affects GDP development in selected countries. As it has been shown, the significance of the aforementioned relationship depends on the country [7]. It has also been stated that energy prices affect GDP to a greater extent in the developed countries than in the developing countries [8].

The first part of the article presents the methodology of the study and data taken into account in the analysis conducted. The second part of the article contains study results for particular raw materials. The whole article ends with a summary which discusses the study results presented in the previous chapter and the references.

\section{Methodology and data for analysis}

The aim of this article is to examine to what extent energy raw materials prices volatility impacts GDP fluctuation with regard to selected European countries [9]. In order to determine the aforementioned relationship, the linear regression was used. It was carried out using Excel and data analysis function (linear regression).

For the linear regression analysis - showing the relation between dependent variable and independent variables - to be carried out properly, data for the study should be selected appropriately in the first place. This article analyses the influence of particular energy raw materials (their prices volatility) on GDP fluctuation with respect to selected European 


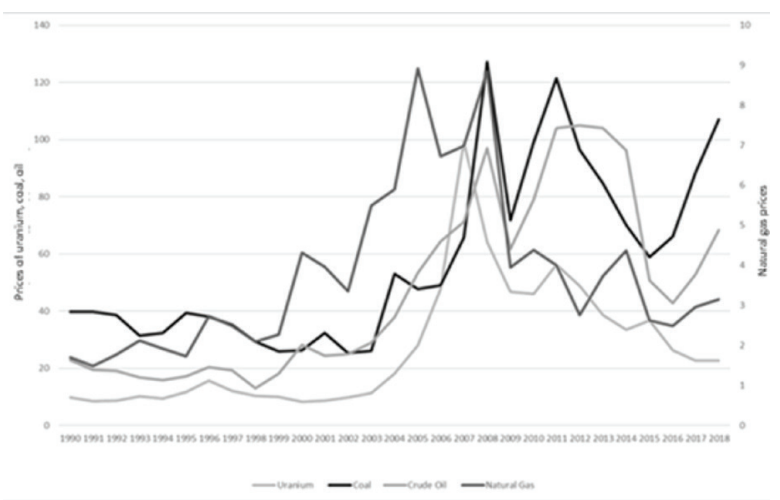

Fig. 1. Energy raw material prices. Source: own elaboration based on [11] Rys. 1. Ceny surowców energetycznych. Źródło: opracowanie własne na podstawie [11]

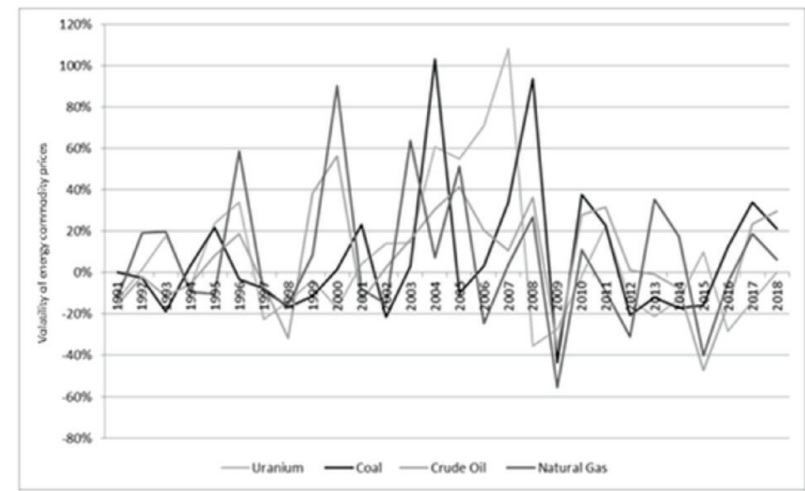

Fig. 2. Volatility of energy raw materials prices taken into account for the analysis. Source: own elaboration based on [11] Rys. 2. Zmienność cen surowców energetycznych wzięty pod uwagę w analizie. Źródło: opracowanie własne na podstawie [11]

countries. Taking the above into consideration, raw materials prices (historical data) and GDP values for the selected countries are fundamental data. Figure 1 shows the prices of energy raw materials. The prices of the following raw materials were taken into account for the analysis: coal, crude oil, natural gas and uranium. The aforementioned raw materials are the base for electricity generation. It should also be stressed that they constitute more than $85 \%$ of the energy sources in the EU [10].

Figure 2 shows energy raw material prices volatility in the analysed period, i.e. in the years 1991-2018, as it is the main focus of the study.

As shown in Table 1, the correlation between the volatility of particular energy raw material prices is not significant. Taking the above into consideration, data considered as independent variables were taken into account in the analysis.

Within European countries, 46 countries can be distinguished. For the purpose of the analysis, 33 countries were taken into account. The remaining 13 countries were not analysed due to a lack of data. The following countries were not analysed: Bosnia and Herzegovina, Croatia, Montenegro, Estonia, Liechtenstein, Lithuania, North Macedonia, Moldova, Monaco, San Marino, Serbia and the Vatican City.

The analysis covered the period between 1990 and 2018.

\section{Study results}

Based on the assumptions presented in the previous chapter, an appropriate study of the relationship between energy raw material prices volatility and GDP fluctuation with regard to selected European countries was carried out. Firstly, the coefficient of determination of independent variables to dependent variable (R squared) was determined. This coefficient value determines to what extent the independent variables describe the dependent variable. The study results are presented in Table 2.

Based on the results obtained, it can be generally stated that energy raw material prices volatility describes GDP fluctuation with regard to selected European countries within the range of nearly $14 \%$ to $70 \%$. As it can be readily seen from Table 2 - Norway and the Russian Federation are the countries where GDP fluctuation depends on raw materials prices volatility to the greatest extent. In the case of the first of the aforementioned countries, GDP fluctuation depends on raw material prices volatility in $70 \%$, and in the case of the second one this value slightly exceeds $64 \%$. In the case of Poland, this value is at the level of nearly $45 \%$, and for all the EU countries it is close to $40 \%$. This means that energy raw materials prices volatility describes GDP fluctuation in $40 \%$, thus the raw materials prices shape the level of dependent variable in $40 \%$. As it can also be seen, the countries that mainly depend on energy raw materials prices volatility, rely on extraction and processing of these resources.

The further part of the article examines, which of the energy raw materials prices volatilities are of particular significance for development of GDP fluctuation with regard to selected European countries. The significance of particular 
Tab. 1. Correlation matrix showing relation between the energy raw material prices taken into account for the analysis. Source: own elaboration Tab. 1. Macierz korelacji pomiędzy zmiennością cen surowców wziętych pod uwagę w analizie. Źródło: opracowanie własne

\begin{tabular}{lrrrr}
\hline & Uranium & Coal & Crude Oil & Natural Gas \\
\hline Uranium & 1 & & & \\
Coal & 0.223376 & 1 & & \\
Crude Oil & 0.263144 & 0.489415 & 1 & 1 \\
Natural Gas & 0.056714 & 0.181226 & 0.640421 & 1 \\
\hline
\end{tabular}

Tab. 2. R squared for selected European countries. Source: own elaboration Tab. 2. R kwadrat dla poszczególnych krajów Europy. Źródło: opracowanie własne

\begin{tabular}{|c|c|c|c|}
\hline & $\mathbf{R}$ & R-square & Adjusted R2 \\
\hline Norway & 0.837701335 & 0.7017435 & 0.649872836 \\
\hline Russian Federation & 0.803203622 & 0.6451361 & 0.583420591 \\
\hline Kazakhstan & 0.739889213 & 0.547436 & 0.468729273 \\
\hline Ukraine & 0.739135325 & 0.546321 & 0.467420339 \\
\hline Romania & 0.717212237 & 0.5143934 & 0.42994007 \\
\hline Belarus & 0.704794402 & 0.4967351 & 0.409210828 \\
\hline Poland & 0.667659168 & 0.4457688 & 0.349380724 \\
\hline Hungary & 0.644451231 & 0.4153174 & 0.313633457 \\
\hline European Union & 0.63242485 & 0.3999612 & 0.295606615 \\
\hline Czech Republic & 0.631245168 & 0.3984705 & 0.293856629 \\
\hline Slovak Republic & 0.624343211 & 0.3898044 & 0.283683479 \\
\hline Luxembourg & 0.618838512 & 0.3829611 & 0.275649991 \\
\hline Denmark & 0.609045378 & 0.3709363 & 0.261533885 \\
\hline France & 0.608565234 & 0.3703516 & 0.260847582 \\
\hline Sweden & 0.598647339 & 0.3583786 & 0.246792313 \\
\hline Spain & 0.59780066 & 0.3573656 & 0.245603129 \\
\hline Andorra & 0.592256535 & 0.3507678 & 0.237857856 \\
\hline Greece & 0.591566743 & 0.3499512 & 0.236899248 \\
\hline Switzerland & 0.588275624 & 0.3460682 & 0.232340942 \\
\hline Netherlands & 0.587448363 & 0.3450956 & 0.231199159 \\
\hline Belgium & 0.587039351 & 0.3446152 & 0.230635235 \\
\hline Italy & 0.584439958 & 0.3415701 & 0.22706051 \\
\hline Austria & 0.581491561 & 0.3381324 & 0.223025033 \\
\hline United Kingdom & 0.557481255 & 0.3107853 & 0.190921932 \\
\hline Finland & 0.555799621 & 0.3089132 & 0.188724213 \\
\hline Malta & 0.55180396 & 0.3044876 & 0.183528934 \\
\hline Germany & 0.548700211 & 0.3010719 & 0.179519212 \\
\hline Iceland & 0.530408473 & 0.2813331 & 0.156347609 \\
\hline Ireland & 0.524784914 & 0.2753992 & 0.149381676 \\
\hline Slovenia & 0.522713007 & 0.2732289 & 0.146833912 \\
\hline Portugal & 0.505472037 & 0.255502 & 0.126024064 \\
\hline Turkey & 0.468249248 & 0.2192574 & 0.08347603 \\
\hline Bulgaria & 0.4043057 & 0.1634631 & 0.017978421 \\
\hline Albania & 0.375867211 & 0.1412762 & -0.008067116 \\
\hline
\end{tabular}

independent variables for the formation of a dependent variable is determined by the value "p". If this value is below 0.05 , then it can be assumed that the influence of a particular energy raw material (its volatility) affects development of GDP fluctuation of a selected country (bearing in mind importance of development of GDP fluctuation depended on energy raw materials prices volatility presented in Table 2).

Firstly, it was examined whether uranium prices volatility affects GDP fluctuation with regard to selected European countries. In the case of this energy raw material, it can be stated that it affects GDP fluctuation in the following countries: Norway, Kazakhstan, the Czech Republic, Slovakia, Luxembourg, Greece, Great Britain, Iceland and Ireland. The results are presented in Table 3.

With regard to all the aforementioned countries, an increase of the raw material price results in raise of GDP value in particular countries. Nevertheless, it should be remem- bered that with regard to all these countries (despite of Norway) the influence is not significant. As shown in Table 3, Polish GDP fluctuation does not depend on the volatility of uranium prices. However, with regard to all European countries, there is such relation and similarly as in the case of the countries where GDP fluctuation depends on volatility of uranium prices, an increase of this raw material price results in raise of European GDP value.

Coal is another energy raw material subject to analysis. From the point of view of Poland and its resources, this raw material's volatility seems to be important for development of Polish GDP fluctuation. It should be remembered that in the case of Poland, raw materials prices volatility is described by GDP fluctuation to the extent of $35 \%$. The results with regard to this raw material are presented in Table 4.

Analyzing coal, it should be stated that its volatility - from the perspective of GDP development in particular countries - 
Tab. 3. Uranium. Source: own elaboration

Tab. 3. Uran. Źródło: opracowanie własne

\begin{tabular}{lcccc}
\hline & Coefficient & Standard error & t-stat & p-value \\
\hline Norway & 0.080798948 & 0.037019744 & 2.183 & 0.03953308 \\
Russian Federation & 0.156415905 & 0.084070475 & 1.861 & 0.0756441 \\
Kazakhstan & 0.221321121 & 0.083553753 & 2.649 & 0.01434619 \\
Ukraine & 0.168238325 & 0.089459194 & 1.881 & 0.07274665 \\
Poland & 0.103200273 & 0.05526958 & 1.867 & 0.07466886 \\
European Union & 0.092047291 & 0.042091504 & 2.187 & 0.03918428 \\
Czech Republic & 0.159416512 & 0.066748681 & 2.388 & 0.02552385 \\
Slovak Republic & 0.128176127 & 0.055924331 & 2.292 & 0.03139331 \\
Luxembourg & 0.106124325 & 0.047251593 & 2.246 & 0.03461126 \\
Greece & 0.123226289 & 0.057262678 & 2.152 & $\mathbf{0 . 0 4 2 1 3 4 0 4}$ \\
United Kingdom & 0.113531674 & 0.044862042 & 2.531 & $\mathbf{0 . 0 1 8 6 8 2 7 2}$ \\
Iceland & 0.157013225 & 0.067862082 & 2.314 & $\mathbf{0 . 0 2 9 9 6 9 2 4}$ \\
Ireland & 0.119645996 & 0.050018041 & 2.392 & $\mathbf{0 . 0 2 5 3 1 7 4 4}$ \\
\hline
\end{tabular}

Tab. 4. Coal. Source: own elaboration

Tab. 4. Węgiel. Źródło: opracowanie własne

\begin{tabular}{lcccc}
\hline & Coefficient & Standard error & t-stat & p-value \\
\hline Norway & 0.064237212 & 0.042684998 & 1.505 & 0.14595655 \\
Russian Federation & 0.215552221 & 0.096936059 & 2.224 & 0.03627551 \\
Kazakhstan & 0.188674173 & 0.096340262 & 1.958 & 0.06241738 \\
Ukraine & 0.245379708 & 0.103149432 & 2.379 & 0.02605036 \\
Romania & 0.182837934 & 0.087034116 & 2.101 & 0.04682431 \\
Poland & 0.17676199 & 0.063727668 & 2.774 & 0.01080227 \\
Hungary & 0.144004921 & 0.060068549 & 2.397 & 0.02502887 \\
European Union & 0.103543184 & 0.048532907 & 2.133 & 0.04377663 \\
Slovak Republic & 0.138605839 & 0.064482618 & 2.15 & $\mathbf{0 . 0 4 2 3 4 7 7}$ \\
Denmark & 0.109643216 & 0.050794667 & 2.159 & $\mathbf{0 . 0 4 1 5 6 0 2 7}$ \\
France & 0.110317463 & 0.051402283 & 2.146 & $\mathbf{0 . 0 4 2 6 4 2 3 9}$ \\
Switzerland & 0.113000685 & 0.048517842 & 2.329 & $\mathbf{0 . 0 2 9 0 0 0 6 8}$ \\
Netherlands & 0.110678409 & 0.052790872 & 2.097 & $\mathbf{0 . 0 4 7 2 3 0 9}$ \\
Belgium & 0.115090659 & 0.053699647 & 2.143 & $\mathbf{0 . 0 4 2 9 0 1 7 4}$ \\
Austria & 0.112380899 & 0.054151541 & 2.075 & $\mathbf{0 . 0 4 9 3 2 7 1 8}$ \\
Germany & 0.118710708 & 0.055234421 & 2.149 & $\mathbf{0 . 0 4 2 3 7 3 2 3}$ \\
\hline
\end{tabular}

Tab. 5. Crude oil. Source: own elaboration

Tab. 5. Ropa naftowa. Źródło: opracowanie własne

\begin{tabular}{lcrrr}
\hline & Coefficient & Standard error & t-stat & \multicolumn{1}{c}{ p-value } \\
\hline Norway & 0.253462306 & 0.07149273 & 3.545 & $\mathbf{0 . 0 0 1 7 2 6 3 3}$ \\
Russian Federation & 0.380692704 & 0.162357358 & 2.345 & 0.0280377 \\
Kazakhstan & 0.217617048 & 0.161359462 & 1.349 & 0.19058089 \\
Ukraine & 0.262289238 & 0.172764082 & 1.518 & 0.14259264 \\
Poland & -0.031800496 & 0.106736914 & -0.3 & 0.76842868 \\
European Union & -0.012928238 & 0.081287341 & -0.16 & 0.87502279 \\
\hline
\end{tabular}

is much more important that changes in the uranium prices. As regards coal prices volatility, it is crucial for 13 countries, and in the case of uranium, the number of countries amounts to 9. As shown in Table 4, coal prices volatility is not of significant influence on GDP development only with regard to two countries, these are: Norway and Kazakhstan. It is also worth noting that in the case of Poland, coal prices in the context of GDP are the most important among the mentioned countries.

Cude oil is another energy raw material subject to analysis. The results obtained with regards to this variable are presented in Table 5.

In the case of this raw material, crude oil prices volatility affects GDP fluctuation only with regard to the following two countries: Norway and the Russian Federation. The results obtained for these two countries should be beyond any doubt, taking into consideration the fact that their economies are based on the extraction and processing of crude oil itself. Admittedly, in the case of Poland and EU countries crude oil prices volatility is not important (according to the study results), nevertheless, even if it is assumed that there is some relation with regard to this raw material, it should be stated that it is negative, i.e. the increase in crude oil prices causes the Polish GDP decrease, as well as for the EU in general.

Natural gas is the last energy raw material subject to analysis. The results obtained for this study are presented in Table 6 .

According to the study results, presented in the table hereinabove, natural gas prices volatility has no significant impact on GDP fluctuation with regard to selected European countries. Even for countries like Norway and the Russian Federation. The study results concerning this scope can be in- 
Tab. 6. Natural gas. Source: own elaboration

Tab. 6. Gaz ziemny. Źródło: opracowanie własne

\begin{tabular}{lcccc}
\hline & Coefficient & Standard error & t-stat & p-value \\
\hline Norway & -0.00838149 & 0.048773345 & -0.17 & 0.86506189 \\
Russian Federation & 0.039479241 & 0.110762471 & 0.356 & 0.72476637 \\
Kazakhstan & -0.002029172 & 0.110081693 & -0.02 & 0.98545214 \\
Ukraine & -0.015972689 & 0.117862085 & -0.14 & 0.89337972 \\
Romania & 0.110692127 & 0.099448171 & 1.113 & 0.27717936 \\
Belarus & 0.102067051 & 0.101122094 & 1.009 & 0.32331074 \\
Poland & 0.072937569 & 0.072817423 & 1.002 & 0.32693501 \\
European Union & 0.043732748 & 0.055455367 & 0.789 & 0.43839253 \\
\hline
\end{tabular}

terpreted in such a way that crude oil is much more important for the economic situation of these countries than natural gas.

\section{Summary}

According to the analysis conducted, raw materials prices volatility affects GDP fluctuation in selected European countries. This dependence is particularly evident in the case of countries that are involved in the extraction and processing of particular energy raw materials. It concerns the countries such as Norway and the Russian Federation. In the case of Norway, crude oil and uranium have the greatest impact on GDP fluctuation. With regard to the Russian Federation, crude oil and coal prices volatility are the most significant. According to the study carried out, countries within the con- tinent in question, depend primarily on resources such as uranium and coal. In the case of Poland, only the volatility of coal prices has an impact on GDP fluctuation. It should also be noted that within the European countries in question, GDP of Poland depends on coal prices volatility to the greatest extent. Considering the European Union countries, these are uranium and coal prices volatilities that mainly influence GDP development. Summing up the study results, it should be stated that coal and uranium are still significant for GDP fluctuation development with regard to selected European countries.

This paper was supported by the AGH University of Science and Technology [No. 16.16.100.215] 


\section{Literatura - References}

1. Geise, A. Wpływ cen ropy naftowej na produkcję i inflację w wybranych państwach unii europejskiej, Metody ilościowe w badaniach ekonomicznych 2015, Vol. XVI/3, 48-59.

2. Hamilton, J. D. Nonlinearities and the Macroeconomic Effects of Oil Prices, Macroeconomic Dynamics 2011, 15, 364-378.

3. Bergmann, P. Oil price shocks and GDP growth: Do energy shares amplifycausal effects? Energy Economics Energy Economics 2019, 80, 1010-1040.

4. Deutsche Bundesbank. The price of crude oil and its impact on economic activity in the industrial countries, [in:] Monthly Report 2012, June, 27-49.

5. BP. The Statistical Review of World Energy 2006, http://www.bp.com/statisticalreview, 07/12/2019.

6. Jinke, L.; Hualing, S.; Dianming, G. Causality relationship between coal consumption and GDP: Difference of major OECD and non-OECD countries Applied Energy 2008, 85, 421-429.

7. Soytasa, U.; Sarib, R. Energy consumption and GDP: causalityrelationship in G-7 countries and emergingmarkets, Energy Economics 2003, 25, 3337.

8. Chontanawat, J.; Lester, C. H.; Pierse, R. Does energy consumption cause economic growth?: Evidence from a systematic study of over 100 countries Journal of Policy Modeling 2008, 30, iss. 2, 209-220.

9. www.worldbank.com, 08/12/2019.

10. Atlas energii, Fakty I dane o energetyce odnawialnej w Europie 2018, https://pl.boell.org/sites/default/files/atlas_energii.pdf, 09/12/2019.

11. www.indexmundi.com, 09/12/2019.

\section{Wpływ zmienności cen surowców energetycznych na zmienności wartość produktu krajowego brutto dla poszczególnych krajów Europy}

$W$ artykule poddano badaniu zmienność cen surowców energetycznych, do których zaliczono: uran, węgiel, ropę naftową oraz gaz ziemny, na zmienność produktu krajowego brutto poszczególnych krajów Europy. Badanie przeprowadzono przy użyciu regresji liniowej, w której zmienność cen surowców określono jako zmienne niezależne a zmienność PKB jako zmienna zależną. W artykule wzięto pod uwage 33 kraje Europy, a badany okres obejmował 28 lat (od roku 1990 do roku 2018). Jak wykazano w badaniu zmienność cen surowców energetycznych wplywa na zmienność PKB szczególnie dla krajów zajmujących się ich wydobyciem oraz przetwarzaniem. Zwrócono również uwagę na fakt, iż najistotniejszymi surowcami energetycznymi, które maja znaczenie dla krajów Europy to uran oraz wegiel. W przypadku ropy naftowej zmienność tego surowca okazała się być istotna tylko dla dwóch krajów tj. Norwegii oraz Federacji Rosyjskiej. Zaskoczeniem okazał się fakt, iż zmienność cen gazu ziemnego w nieznacznym stopniu wpływa na zmienność PKB poszczególnych krajów Europy.

Słowa kluczowe: produkt krajowy brutto, surowce energetyczne, zmienność cen 